\title{
The First Buddhist Cantata in the World; Piriniwanmangallaya (The Death of the Lord Buddha), A New Approach to Modern Music in Sri Lanka
}

\author{
S.M.D.N.K.Senevirathne \\ Lecturer (Probationary), Department of Fine Arts, Faculty of Arts, University of Peradeniya, \\ Sri Lanka
}

\begin{abstract}
The western musical tradition has been applied into variety of indigenous music genres covering various themes. Some of them tend to imitate the original western music form while others are accosted with the indigenous musical tradition.

Considerable numbers of Sri Lankan music lovers are showing greater enthusiasm about western music and composers are especially interested in adopting western musical styles to local musical productions. Cantata is a newly introduce musical form to the Sri Lankan music context where the awareness about it, is limited to some local western musicians and few oriental musicians. Generally Cantata is a form of western music which has its own unique musical structure.

Detailed study about musical structure of western Cantata will facilitate the Sri Lankan musicians to have a better understanding about Cantata form and how such musical form could be used in local compositions.

The main objective of this research is to identify the original elements of a Cantata form and the influence of western Cantata style on contemporary and modern music traditions of Sri Lanka.

Premasiri Kemadasa, a Sri Lankan modern music composer has composed Piriniwanmangallaya (Death of the Lord Buddha) with the use of western, oriental and Sri Lankan Folk music influences and named it as the 'first Buddhist Cantata' in the world. (Usually, Cantata is associated with Christian religion).This is a notable instance where the local musicians have attempted to incorporate Cantata form into Sri Lankan contemporary music. Singing Sri Lankan folk melodies according to western style has resulted in a strange impression and has created a certain amount of disharmony to the theme of the play. Furthermore, the way in which ordinary people perceive the death of the Buddha, especially grief associated with it has not been adequately expressed, perhaps due to the use of six voice ranges as in the western Cantata form.

This is a qualitative research that describes the specific situations in detail using research strategies/tools such as literature surveys, interviews and discussions etc. Both primary and secondary sources were used in order to obtain data as well.
\end{abstract}


Keywords: Cantata, World First Buddhist Cantata (Piriniwanmangallaya), Premasiri Kemadasa, Sri Lankan folk music, Modern Sri Lankan Music, Influence of Western Music Introduction

Music around the world has been customarily described by their style. Musical style is one of the fundamental components that expresses the cultural identity of a population and used as an important criteria to distinguish different cultures. The musical styles could be classified broadly as western and non-western based upon the different styles with different implications. When consider about human history, music has been used in various social contexts such as religious, educational, political, economic and in other cultural aspects. According to individual perception, one may argue that one of these styles (Western or Nonwestern) is more musical than other, having a sense of rhythm, or absolute pitches, or an excellent melody, it is totally a cultural specific matter. Due to the usage and the popular demand for it, music has become one of the expressive art forms in any society.

A British ethnomusicologist and social anthropologist John Blacking recognised the world as a group of music. He pursued the interest of studying their borderlines than the centres, but he wanted to make sure that his readers understood a major point: all music is equally valuable, or all music is equal degree music. He considered all humans to be fundamentally musical, arguing that musicality is an inherently human quality. But all music is worthy of attention, and so are the musical utterances of each human. (Nettle, 2005, p.55)

When considering the introduction of new musical material to a well-established musical culture, the material introduced will not be considered as new if the content is related to already existing musical structure. Even when an extraneous musical material is introduced, it might not be accepted as part of its musical culture if it cannot be related to the musical psyche of the society. A new word, after all, does not enter a language, even though it may fit the phonology, unless there is a way in which the culture can make use of its meaning or conceptualization. In music, too, rather than accepting just anything that conforms to its style, a culture might not consider a newly introduced tune to be part of its music unless it also can be related to specific extant musical works such as songs. (Nettle, 2005, p.55)

Alan Merriam, an American cultural anthropologist and ethnomusicologist mentioned, all people, in no matter what culture, must be able to place their music firmly in the context of the totality of their beliefs, experiences, and activities, for without such ties, music cannot exist" (Nettle, 2005, p. 230). Consequently music plays a role of great importance in cultural, philosophical, political and ceremonial life of a society.

In twentieth century Western music elements and singing styles had a major influence on other traditional, folk and non-western musical compositions. This western influence sometimes altered the musical structures in eastern practices and blended well within the local musical styles. But in some instances these kind of influence were accepted for only a limited time period when a society was subjected to enforce implementations, especially during invasions and forceful occupation of countries. The post revival of original musical forms aftermath of such incidents is well documented in musical literature.

A similar phenomenon can be seen in Sri Lanka. In the colonial period, Sri Lanka was ruled by Portuguese, Dutch and English from fifteenth century to mid twentieth century. Some of their 
musical styles influenced local musical forms and was accepted to a certain degree, where local lyrics were blended with western melodies and rhythms to produce songs that were especially used in contemporary Sri Lankan light songs as well as in religious ceremonies.

Main objectives of this research are to examine the structure and the origin of the western Cantata form and the appropriateness of incorporating such a form with western music elements to present a religious theme related to Buddhism with a special emphasis on music. Sri Lankan musical domain is well exposed to various forms of western musical styles, Cantata is a newly introduced musical form to the Sri Lankan musical traditions. It is a type of music with many vocal and instrumental parts. Cantata has been noticed from ancient periods (The earliest Cantatas were composed by musicians such as Vincenzo Galilei, and Giulio Caccini in Florence in the sixteenth century) but have been developed in the Baroque era. (Larocque: 2012)

The earliest Cantatas were sung by a single voice with a single instrument. A Cantata can be structured with many thematic elements as well as structural elements in many forms. In general there were two basic types of Cantata Cantata da Chiesa (Church or Sacred Cantata) Cantata da camera (Chamber or Secular Cantata)

Sacred Cantatas were composed for the liturgy or other occasions in the church and many secular Cantatas were also composed for the events of the nobility. (Terry: 1925, p.33)

At present the term Cantata is used in both western and eastern music traditions. Composers from different cultures tend to inter-mix their own traditions as well. Many Asian countries compose Cantatas based on the respective social and religious concepts and beliefs. For an example china has composed a Cantata named "Chinese Myth Cantata".

(Moh-wei Chen, D.M.A: 2009),

A Cantata has an own unique structure such as Sinfonia, Recitative, Aria, Duets, Trios, Chorus. Thus it becomes clear that there is a general structure to compose a Cantata and there are many vocal and instrumental parts which should be included in a Cantata. The structure may change depending on the composer's background and approaches. However, every Cantata contains common elements of Cantata form.

A well-known Sri Lankan music composer Premasiri Kemadasa, composed a Cantata based on the death of the Lord Buddha (Piriniwanmangallaya) and he titled it as "Worlds' first Buddhist Cantata".(Hettiarachchi, 2016) 


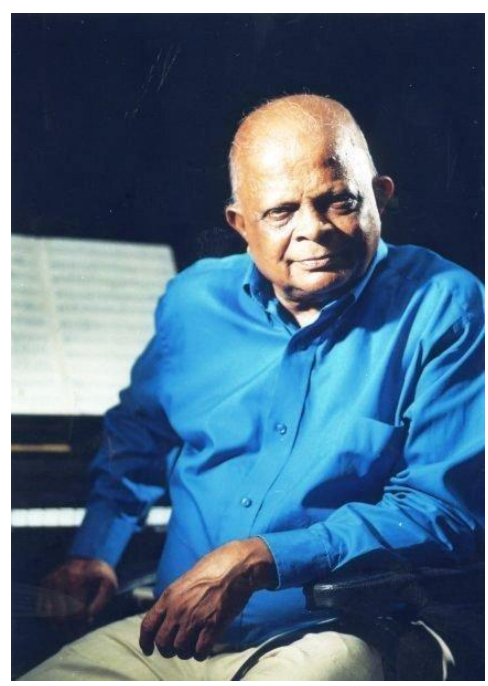

Figure 1: Image of Premasiri Kemadasa

Premasiri Kemadasa (1937-2008) can be introduced as an outstanding experimental Sri Lankan musician who established a unique music sub-culture in Sri Lankan music traditions. He was one of the pioneers of a modern style of film music, stage drama music, teledrama music as well as light song music for Sri Lanka, based on folk melodies and his own inventions, sometimes inspired by Western classical pieces. He offered several forms of experimental music in to the art stream of the country and tried to give a new experience to his audience. He tried to introduce western music forms and genres such as Opera, Ballet, Symphony, Cantata etc. to modern Sri Lankan music. (Kemadasa; 2018)

According to Kemadasa, Piriniwanmangallaya, the world first Buddhist Cantata was influenced by the libretto from folk poems (accompanied with dancing forms practiced in the low country region of Sri Lanka) and applied Sri Lankan folk melodies along with North Indian Classical music and certain elements from western music to depict the grieving sense of Lord Buddha's Death.

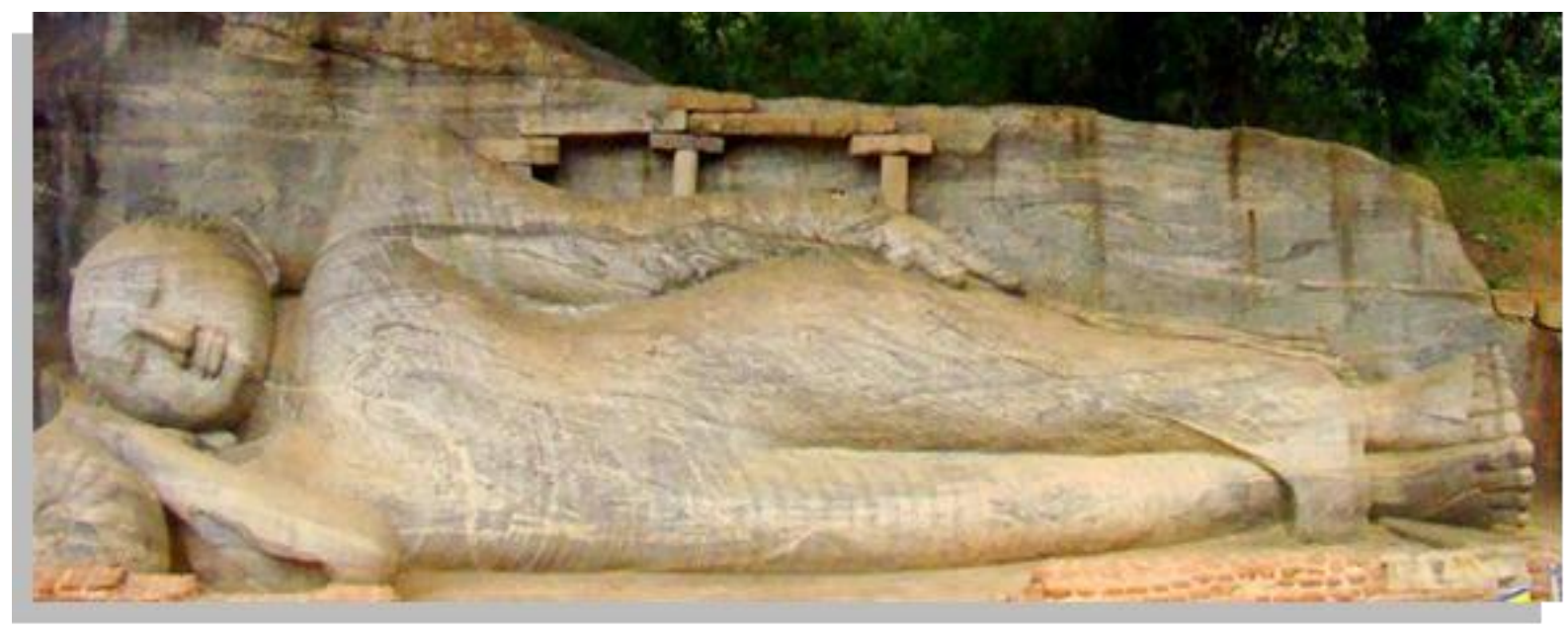

Figure 2: Sculpture of the Load Buddhas' Death (Parinibbana) 
The introduction of such composition to Sri Lankan music can be considered as a significant achievement by the composer. According to the buddhist philosophy and the sociocultural ideology in Sri Lanka, Buddha's death is considered as a deep philosophical theme. Kemadasa tried to represent Buddha's death as an emotionally sensitive incident through the use of Sri Lankan folk melodies with combination of some western music elements. Kemadasa has not directly applied folk melodies for his composition but he has used some styles such as singing of prose (similar to recitatives), traditional lamentation poems, singing with sound vibrations to make visual images. Further he got some influences from Sri Lankan traditional folk melodies such as Buddhist recitals (Pirith chanting), Harvest songs (Nelum Gee), Lamentation songs etc. to create further meaningful impact.

Similarly when the time that Lord Buddha had come to the end of his life and was ready to attain the death, Kemadasa has used Lamentation poem melodies with soprano solo voices to emphasize the sorrowful feeling.Further, he has used the all voice ranges in western music such as Soprano, Mezzo-soprano and Alto for female and Bass, Baritone and Tenor for male. In addition, Kemadasa has used western as well as eastern musical instruments to enrich this musical composition. Sri Lankan percussion and wind instruments such as Udakkiya, Thammattam, Bamboo flute, Horanewa, and North Indian instruments such as Sitar as well as western music instruments like, Oboe, Cello and Violin are some of those instruments he used for this composition.

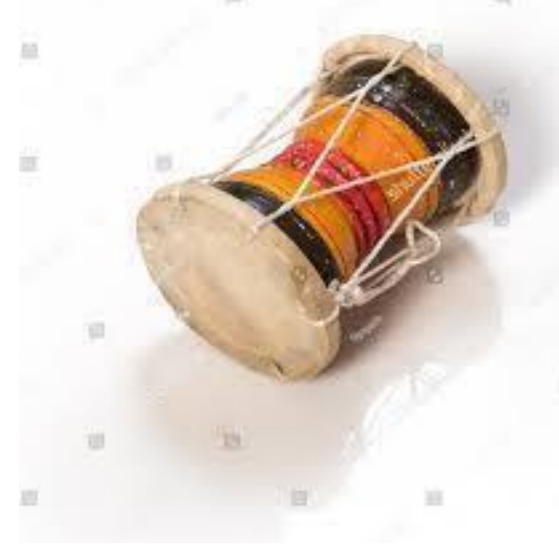

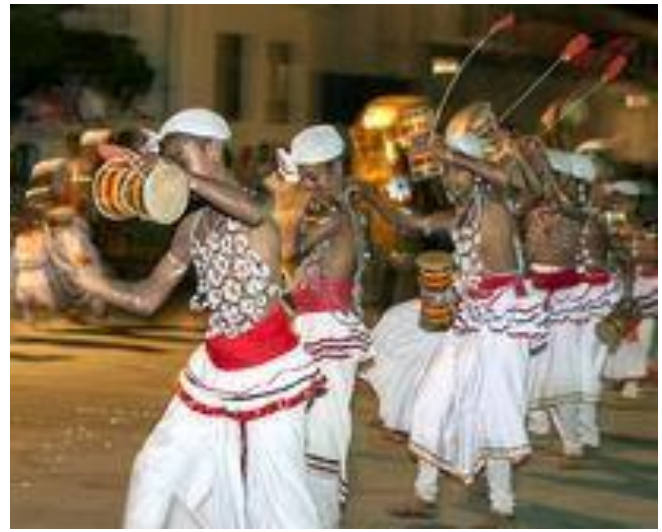

Figure 3: Udakkiya 

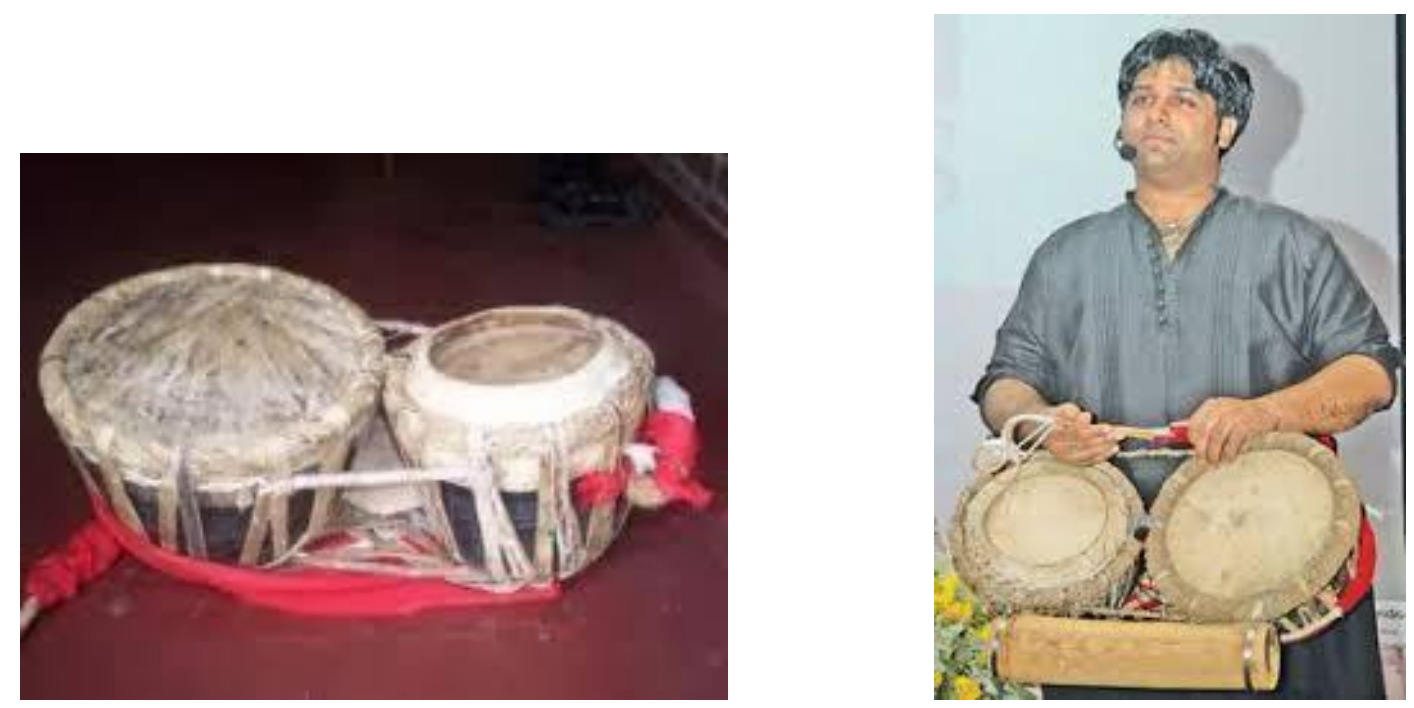

Figure 4: Thammattam
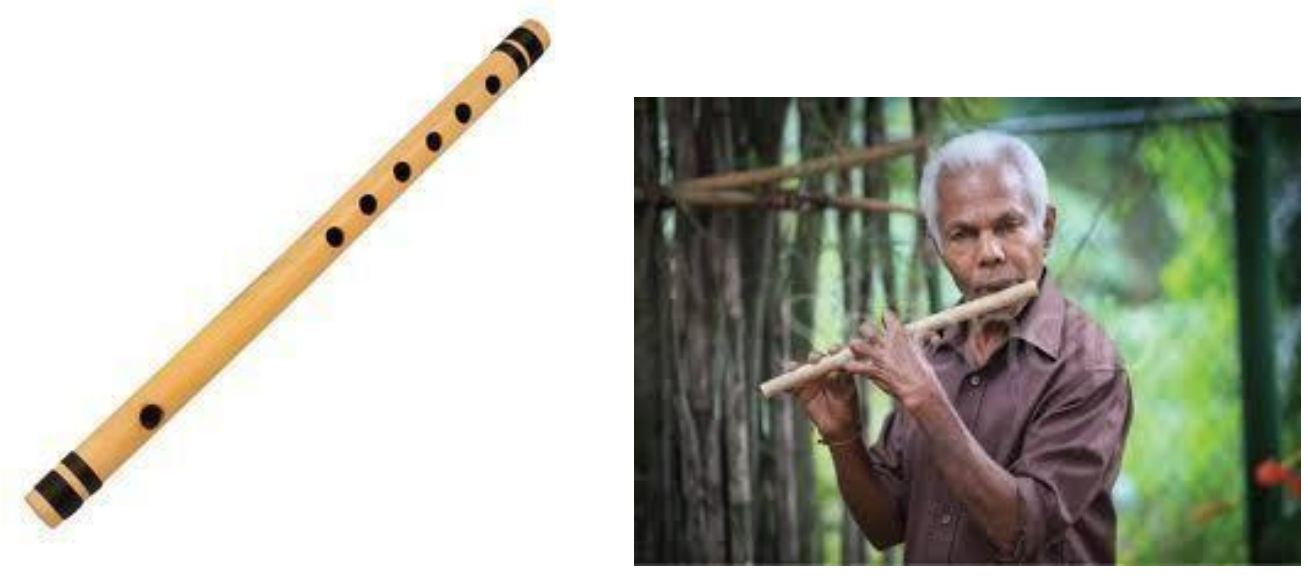

Figure 5: Bamboo Flute
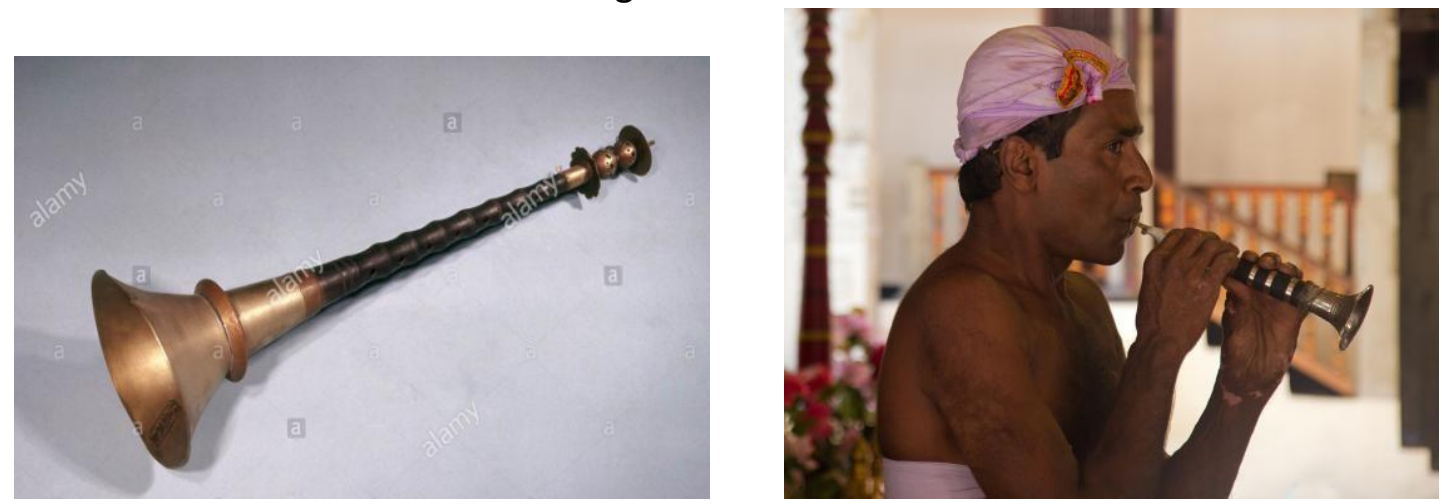

Figure 6: Horanewa

Moreover Kemadasa composed the melody of funeral march by using Percussion instruments called Hewisi, (Dawula, Thammattama and Horanewa) in performing the occasion of Lord Buddha's death. Playing these percussion instruments is a tradition of ordinary local funerals. 
He used this sound as the background melody and it is strongly emphasize the moment of Lord Buddha's death.

\section{Methodology}

This is a qualitative research and both primary and secondary sources were used in order to obtain data. Listening to audio tapes and compact discs of Piriniwanmangallaya and some western Cantatas (Specially J.S. Bach's Cantatas), content analysis of music scores have been used as primary sources. Apart from that, in-depth interviews with focus groups, personal and related discussions with eminent musicians, and participant observations have been conducted to collect data.

The secondary sources that were used for this study include History textbooks, dictionaries, encyclopaedias, interpretive journal articles, magazines, newspaper articles and academic journals.

\section{Results}

Pemasiri Kemadasa has attempted to blend some elements in western, eastern as well as Sri Lankan folk music traditions to compose his "World First Buddhist Cantata", Piriniwanmangallaya. Though Kemadasa has called it a Cantata, a close observation can implies that there are certain differences between the original Cantata form and this particular work. But as a musical composition, he tried to bring out Lord Buddha's death to the international audience with the help of western music.

Linguistic patterns differ from culture to culture. In a country like Sri Lanka, Buddha's death is an incident which gives a melancholy to the buddhist population. Sometimes it is difficult to express a deep philosophy like Lord Buddha's' passing away to the local audience with use of some elements in western music.

In any musical composition, the most important role is played by the musical score. This includes all singing parts such as duets, solos and chorus and also it indicates separate harmony parts, cycling singing parts, counter parts etc. However, Kemadasa has not used a permanent musical score for his composition. According to some of the members of his orchestra, he only had given instructions to the players and they had to adjust the score (Bandara, 2014).

Eg: For Keyboard (This is written according to the North Indian notation system) 


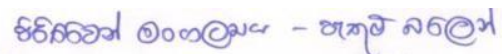

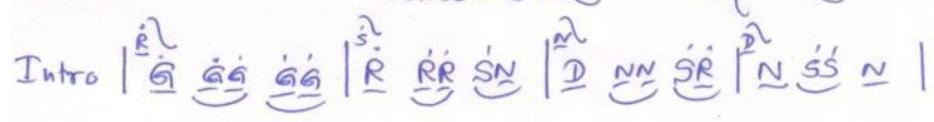

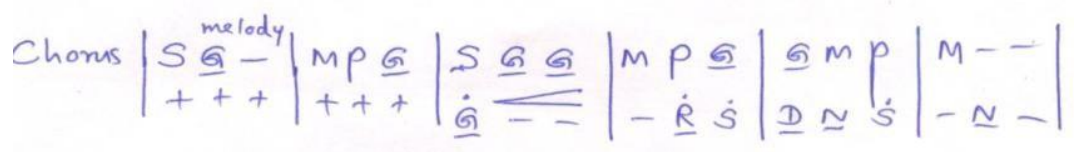

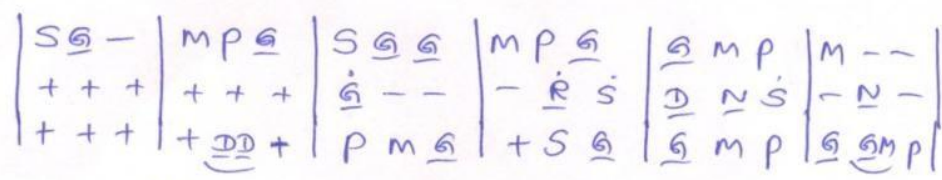

$$
\begin{aligned}
& \text { like Adlib }
\end{aligned}
$$

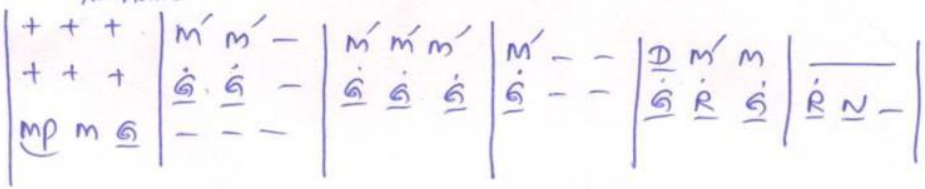



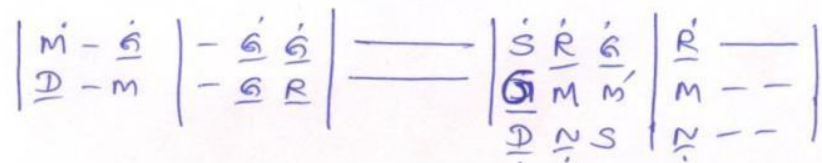

Figure 7: Key boards' Score

For Violins ((This is written according to the western music notation system)

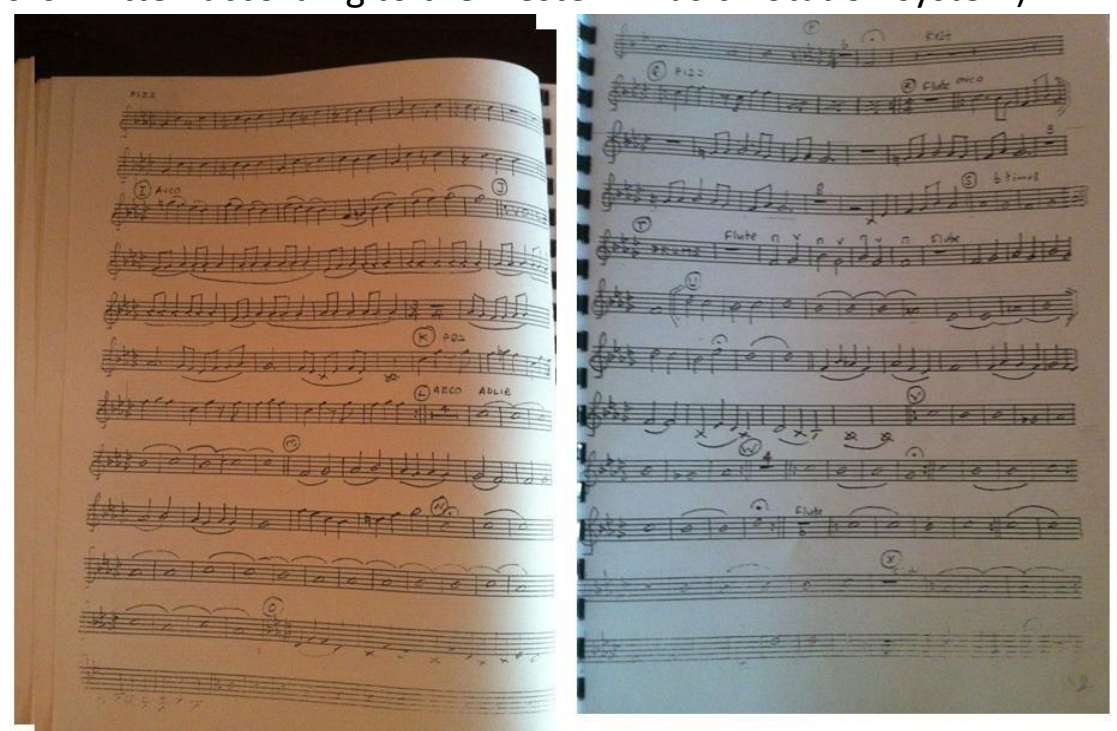

Figure 8: Violins' Score

Kemadasa has used both western and eastern musical instruments to emphasize the theme. The use of oriental instruments like play for funerals at Sri Lanka is a cultural interpretation and it is a good combination to emphasize the miserable feeling caused by Lord Buddha's' 
death. Similarly, he has played oriental flute and Sitar as interlude parts. Mixture of those instruments has been done exceedingly well.

Moreover, where the vocalist is considered, singing Sri Lankan folk melodies according to western style has resulted in a strange impression and has created a certain amount of disharmony to the theme of the play. Additionally, the way in which ordinary people perceive the death of the Buddha, especially grief associated with it has not been adequately expressed, perhaps due to the use of six voice ranges as in the western Cantata form. Some soprano singing parts are not suitable for this composition. Furthermore, it is filled with harmony and slight canonical entries and some of them are indescribably complicated with toning of folk melodies. Sri Lankan folk melodies do have a limited notation systems and it is rather difficult to develop that into a western Cantata style.

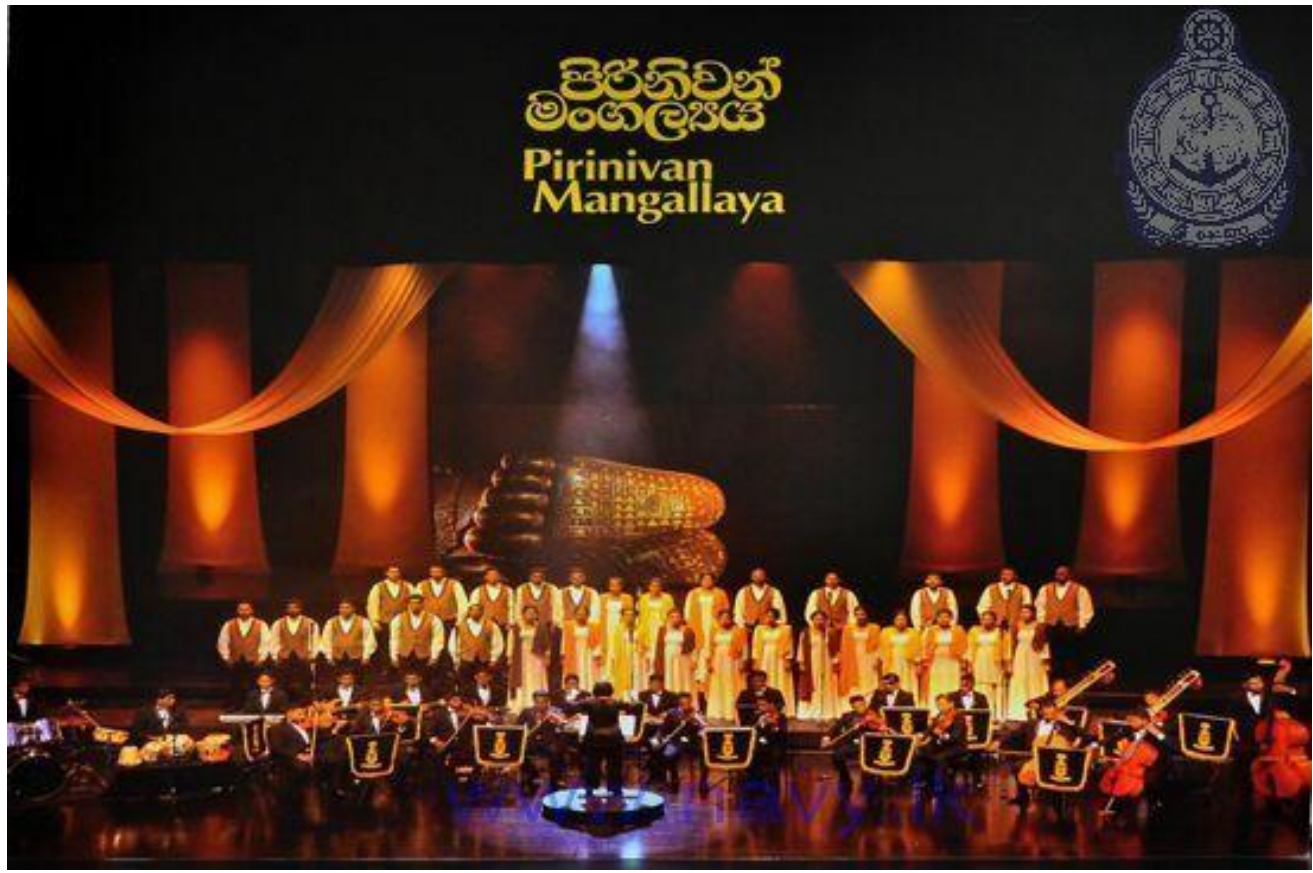

Figure 9: Choir members of the Buddhist Cantata, Piriniwanmangallaya

According to Sri Lankan theorist Tissa Abeysekara, mentioned "the music and the language of Piriniwanmangallaya are not successfully combined together and this combination does not reflect the extreme sadness and the feeling of the 'lack' of Buddha after the parinirvaana" (Abeysekara, 2007:129). If he used the melodic influences of the "Passion songs" (covering the Passion of Jesus, the events leading up to the Crucifixion of Jesus, and emphasising his suffering) or "Requiems" (In Catholic churches, "requiem" refers to a mass celebrated for the dead i.e. any piece of music composed or performed as a memorial to a dead person or a group of people. Requiem is a celebration for the repose of the souls of the dead.), this could have become an excellent work of music. Some Sri Lankan scholars of western music and Eastern music react positively to Kemadasa's Piriniwanmangallaya as a Cantata and they enjoying the novelty and modernity of music. 
Moreover this musical composition could have become a successful masterpiece if Kemadasa wished to come up with a newly written poem that best matches with the theme as well as his intentions. Even though folk music is appropriate for the theme of Lord Buddha's' death, the use of certain elements such as singing styles, harmonic variations, voice ranges are sometimes cannot considered to be suitable for this context.

Whatever the consequences may be, Kemadasa has attempted to bring the local folk melodies into the outer world as well. He has combined all Western, Indian and Folk melodies in order to come up with a unique, modern music style. This composition will encourage further attempts on modern approaches in Sri Lankan contemporary music. In a country littered with self-marketed cultural dilettantes and desperados, Premasiri Kemadasa stands out with his remarkable talent, uncompromising artistic integrity. [Lakshman Joseph de Saram (Professional Western Musician in Sri Lanka)]

\section{References}

Boyd, Malcolm., (1932). The master Musicians Bach. J.M.Dent \& Sons Ltd.

Grout, Donald J., Palisca, Claude V., (1996). A History of western music. W.W. Norden \& Company.

Hanning, Barbara. Russano., (1998). Concise history of Western Music. W.W Norton \& Company.

Nettle, Bruno. (2005), The Study of Ethnomusicology; Thirty-one Issues and Concepts. New edition, Urbana and Chicago: University of Illinois Press.

Pen, Roland., (1992). Introductionto Music. McGraw-Hill International Editions.

Terry, Charles Sanford., (1925). Bach: the Cantatas and oratorios. London: Oxford University Press.

\section{Encyclopaedias and Dictionaries}

Apel, Willi., (1951). Harvard Dictionary of Music. Routledge \& Kegan Pvt Ltd

Benton, Hellen. Hemingway., (1978). Encyclopaedia of Britannica.Vol.no.04. William Benton Publisher.

Fuller, J.A., (1910). Dictionary of Music and Musicians. Vol.no.01. London, Macmillan and Co.Ltd

Scholes, Percy.A., (1970). The Oxford companion of music. $10^{\text {th }}$ edition. New York, Toronto: London Oxford University Press.

\section{Sri Lankan Books written in Sinhala}

Abeysekara.Thissa. (2007) Ayale Giya Sithaka Satahan, Nugegoda, Sarasavi Publishers

\section{News Paper Articles}

Kemadasa,Gayathri. (2018). Choral Ode to Masestro, Daily News, $06^{\text {th }}$ of September 2018, Page 29.

Jayasekara. Shaminda., (2008). "Khemadasa - A 'Master' by all mean". Sunday Times. $02^{\text {nd }}$ November. Page11. 


\section{Online News Paper Articles}

Kumudini Hettiarachchi (2016). Rebirth of 'Pirinivan Mangallaya' Sunday times Sunday,

August 14, 2016 http://www.sundaytimes.lk/160814/plus/rebirth-of-pirinivan-

mangallaya-204562.html On line articles

Larocque. Paul. (2012), An Exploration of Baroque Music, German https://studylib.net/doc/8514546/an-exploraton-of-baroque-music

Accessed on 10.04.2018

Cantata Music (2010), available at https://www.britannica.com/art/cantata-music) The Editors of Encyclopedia Britannica. Accessed on 01.05.2018.

Moh-wei Chen, D.M.A (2009), Myths from afar:Chinese Myth Cantta by Chen Yi, 1997, available at https://china.usc.edu/chen-myths-afar-chinese-myths-cantata-chen-yi-1997. Accessed on 08.05.2018

Thiman. Eric, Discussion of Bach Cantatas, 2007, http://www.bachCantatas.com/Lib/Thiman-Eric.htm. (Accessed on 20.07.2018)

\section{In-depth Interviews}

Bandaera. Daya (Orchestral member of Piriniwanmnagallaya Cantata), 12.08.2017

Perera. Samantha (Choir member of of Piriniwanmnagallaya Cantata), 22.06.2018 Suresh.

Sagara (Orchestral member of Piriniwanmnagallaya Cantata), 09.07.2017

\section{Audio}

Kemadasa, Premasiri. Piriniwanmangallaya, (2011).

https://www.youtube.com/watch?v=EOO0Kj3Rsa8 Downloaded from you tube (Accessed on 02.12.2012)

J.S.Bach Cantata BWV 004; "Christ lay in the bonds of death" (Christ Lag in Todesbanden) (1981). Bach- Ensemble Helmuth Rilling collection, CD no: 98.864. 